\title{
Polymorphism of the stem rust population on avirulence genes in Western Siberia
}

\author{
Skolotneva E.S.*, Kelbin V.N., Piskarev V.V., Salina E.A. \\ Institute of Cytology and Genetics, SB RAS, Novosibirsk, Russia \\ *e-mail: skolotnevaES@bionet.nsc.ru
}

Effective breeding rust resistant wheat varieties relies on monitoring efforts that include field screening of pathogen gene structure and seedling tests conducted in quarantineequipped laboratories. Since 2009, stem rust has appeared among the pathogenic complex in Western Siberia, causing significant damage to wheat crops. A list of avirulence genes identified in the rust population is desirable in order to focus on complementary Sr-resistant genes that can be used in a breeding program. Disease incidence and severity were assessed in Novosibirsk region during 2016-2018. Stem rust responses of wheat varieties with known $S r$-genes (more than 64 entries) were recorded at post-flowering stage using the Roelfs' scale (1992). Infection types (ITs) on seedlings were recorded in 14 days after inoculation addressed to Stakman's scale (1962). Based on field screenings, stem rust population local in Novosibirsk region is polymorphic for most of known avirulence genes. No polymorphism was revealed for genes avirulent to wheat lines with $\operatorname{Sr} 9 e, \operatorname{Sr} 20, \operatorname{Sr} 28, \operatorname{Sr} 29, \operatorname{Sr} 32$, Sr33, Sr39, and $S r 2$ complex. After the seedling test of 20 differential lines, there were polymorphic genes avirulent to $\operatorname{Sr} 7 b, \operatorname{Sr} 6, \operatorname{Sr} 8 a, S r 9 b$, $\operatorname{Sr} 9 e, \operatorname{Sr} 21, \operatorname{Sr} 30, \operatorname{Sr} 36$ and non-polymorphic genes avirulent to $\operatorname{Sr} 11, \operatorname{Sr} 24, \operatorname{Sr} 31$, SrTmp revealed in the local stem rust population. The twelve wheat resistant genes $S r 9 e, S r 11$, Sr24, Sr20, Sr28, Sr29, Sr31, Sr32, Sr33, Sr39, Sr2 complex, and SrTmp are considered effective against stem rust pathogen in Novosibirsk region.

Acknowledgements: The study has been supported by the Budget project 0259-20190001 and RFBR grant No. 17-29-08018. 